\title{
NANOTECHNOLOGY: HoW VOLUNTARY REgulatory Programs Can Both Ease Public Apprehensions and INCREASE INNOVATION IN THE MIDST OF UNCERTAIN FEDERAL REgUlations
}

\author{
Katie Miller*

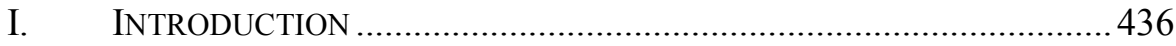

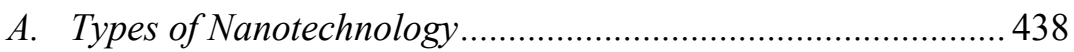 \\ B. The Issue: Regulating Nanotechnology .................................. 440

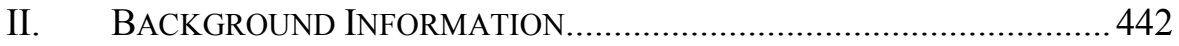 \\ A. Nanotechnology's Possible Problems..................................... 442

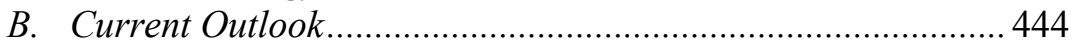 \\ 1. Available Funding for Nanotechnology .......................... 444 \\ 2. Societal Interest in Nanotechnology.................................. 445 \\ 3. Public Confidence and Perceptions ................................. 446

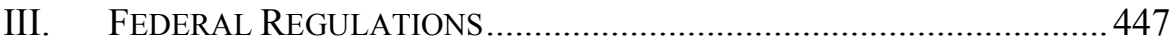 \\ A. Existing Debate Concerning Regulation................................. 447 \\ 1. Environmental Protection Agency: Toxic Substances \\ Control Act .......................................................................... 448 \\ 2. Food and Drug Administration: Federal Food Drug \\ and Cosmetic Act............................................................... 449 \\ 3. Occupational Safety and Health Administration................ 449 \\ 4. Consumer Product Safety Act..........................................450 \\ 5. Other Sources ................................................................... 451 \\ B. Why Federal Regulations for Debate?.................................. 451 \\ C. Problems with Existing Regulations-Short-term and

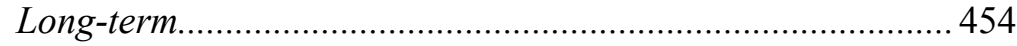 \\ IV. VOLUNTARY REGULATORY PROGRAMS........................................ 457 \\ A. Proposal for State Level Voluntary Regulatory Program........ 457 \\ B. Existing Voluntary Programs in Other Industries ................... 459 \\ C. Advantages of Voluntary Program ......................................... 462

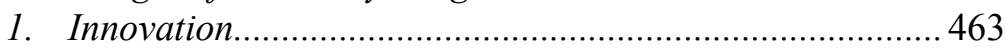 \\ 2. Public Perceptions .............................................................. 463

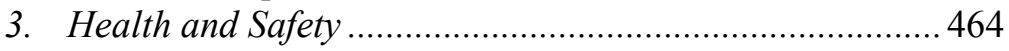 \\ 4. Incentives for Firm Participation ...................................... 465 \\ D. Disadvantages of Voluntary Program .................................... 465 \\ E. How a State Level Program Would Look................................. 467

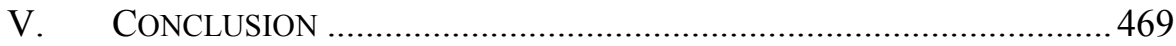




\section{INTRODUCTION}

"Nanotechnology is so new and so untested for potential effects on human health that we do not even know what we don't know."1 Dr. Philip Landrigan, Director of the Children's Environmental Health Center at Mount Sinai School of Medicine, was correct in identifying that the problem of nanotechnology is a complete lack of knowledge, not only on the part of the government and researchers, but also on the part of the public in general. ${ }^{2}$ This lack of knowledge exists as to the potential effects, benefits, uses, and regulations necessary for new nano-containing products.

Nanotechnology is an emerging field concerned with many different kinds of nanoparticles that are each inherently different. ${ }^{3}$ Research involving nanoparticles has been conducted since the 1980s, though the concept of nanotechnology was first discussed at a Caltech American Physical Society meeting in 1959. ${ }^{4}$ In 2001, the National Nanotechnology Initiative ("NNI") was established to focus research efforts on nanotechnology. ${ }^{5}$ The NNI was established by Executive Order under the auspices of the Nanoscale Science, Engineering and Technology ("SET") subcommittee of the National Science and Technology Council. ${ }^{6}$ The NNI is made up of twenty-six ${ }^{7}$ U.S. federal agencies including both the Food and Drug Administration ("FDA") ${ }^{8}$ and the Environmental Protection Agency ("EPA"). ${ }^{9}$ There

* J.D. Candidate, 2011, Indiana University School of Law-Indianapolis; B.S., 2008, Purdue University Krannert School of Management; B.S., 2008, Purdue University School of Science.

1. Steven Higgs, Mama, Dada, and Nano? Subparticles May be Toxic for Kids, THE Progressive, Oct. 2009, at 18.

2. See id.; see also Rory O’Neill, Dangers Come in Small Particles, HAZARDS, JulySept. 2004, at 16, available at http://www.hazards.org/nanotech/nanotechsafety.pdf.

3. Ronald Sandler \& W. D. Kay, The National Nanotechnology Institute and the Social Good, 34 J.L. MED. \& ETHICS 675 (2006) (describing the future of nanotechnology as "a future in which the ability to understand and control matter on the nanoscale leads to a revolution in technology and industry.").

4. History and Future of Nanotechnology, NANOTEChNOLOGY RES. Found., http://www.nanotechnologyresearchfoundation.org/nanohistory.html (last visited Oct. 17, 2010).

5. Nastassja Lewinski, Nanomaterials: What are the Environmental and Health Impacts?, Chem. Eng. Progress, Dec. 2008, at 37. See generally What is Nanotechnology?, NAT'L NANOTECHNOLOGY INITIATIVE, http://www.nano.gov/html/facts/whatIsNano.html (last visited Oct. 17, 2010).

6. 15 U.S.C.A. § 7504 (West 2003); see also Exec. Order No. 12,881, 58 Fed. Reg. 62491 (Nov. 23, 1993), available at http://www.archives.gov/federal-register/executiveorders/pdf/12881.pdf.

7. See Jordan Paradise et al., Developing Oversight Frameworks for Nanobiotechnology, 9 Minn. J. L. ScI. \& TeCh. 399 (2008); Government Departments and Agencies, NAT'L NANOTECHNOLOGY INITIATIVE, http://www.nano.gov/html/about/nniparticipants.html (last visited Feb. 16, 2010).

8. See generally Nanotechnology, U.S. FOOD AND DRUG Administration, http://www.fda.gov/ScienceResearch/SpecialTopics/Nanotechnology/default.htm (last updated May 21, 2010). 
is no set definition of nanotechnology, but according to the NNI, the working definition includes:

(1) $[R]$ esearch and technology development at the atomic, molecular or macromolecular levels, in the length scale of approximately 1-100 nanometer range; (2) creating and using structures, devices and systems that have novel properties and functions because of their small and/or intermediate size; and (3) ability to control or manipulate at the atomic scale. ${ }^{10}$

To put this into perspective, one nanometer is one one-billionth of a meter, and a single strand of hair is 75,000 nanometers in diameter. ${ }^{11}$ Further, it takes ten hydrogen atoms, the smallest element on the periodic table, lined up end-to-end to equal one nanometer. ${ }^{12}$

The current state of the nanotechnology industry is such that scientists are uncertain of what happens when humans breathe, absorb, or ingest engineered nanomaterials. ${ }^{13}$ It has yet to be researched exactly where nanomaterials go in the body and what, if any, effects nanoparticles may have on the health of the human body. If those working directly with nanocontaining products and technologies lack complete knowledge, what chance does the government have in enacting proper regulations? Moreover, what chance does the public have in understanding the risks and benefits of nanotechnology that could, and in many cases do, affect their everyday lives?

This Note proposes a state level voluntary regulatory scheme for regulating nanotechnology. This voluntary program is proposed to only be used until nanotechnology-specific federal regulations are enacted. First, is a discussion of the different types of nanotechnology and potential problems associated with each. Second, this Note addresses the public perceptions of nanotechnology and the current outlook in the industry. Third, is an outline of the existing debate over federal regulations and which regulations are being considered. Fourth, is a description of the proposed state level voluntary regulatory scheme. Finally, this Note explains other successful voluntary regulations and why a similar scheme for nanotechnology will work.

9. The EPA is concerned with the effects of nanotechnology on the environment and supports nanotechnology research. Nanotechnology, U.S. ENVIRONMENTAL PROTECTION AGENCY, http://www.epa.gov/ncer/nano (last updated Feb. 3, 2010).

10. See Paradise et al., supra note 7. See generally NaT'L Nanotechnology INITIATIVE, http://www.nano.gov (last visited Feb. 10, 2010).

11. James Brindell, Nanotechnology and the Dilemmas Facing Business and Government, 83 FLA. B.J. 73, 73 (2009).

12. Id.

13. See Regulating Nanotechnology: A Hardnose Look, NANOPARTiCle News, Feb. 1, 2006, available at 2006 WLNR 24068236. 


\section{A. Types of Nanotechnology}

Nanomaterials come in many different shapes and sizes. Several types of nanomaterials are currently being used in research and can be found in every day consumer products. Each of these types of nanomaterials has different properties, and thus poses different risks. Nanomaterials can be produced in two ways. They can be produced using either a "bottom up" or "top down" process. ${ }^{14}$ "Bottom up manufacturing is the creation of nanomaterials from atoms and molecules." " In contrast, "[t]op down manufacturing is the creation of nanomaterials from their macro-scale counterparts . ..." Top down manufacturing is achieved through several processes, with milling being the method most commonly used. ${ }^{17}$

The principal use of nanomaterials is in drug delivery systems. For this function, gold nanoparticles are used. Gold nanoparticles "provide attractive vehicles for pharmaceutical delivery applications as a result of their size and the unique properties and release mechanisms." ${ }^{\text {"18 }}$ Massachusetts Institute of Technology, for example, has used gold nanoparticles and infrared light to develop a drug delivery system that allows multiple drugs to be released in a controlled fashion. ${ }^{19}$ Gold nanoparticles are effective for drug delivery systems because they melt and release the drugs that are attached to their surfaces when exposed to infrared light. ${ }^{20}$ Nanoparticles of different shapes respond slightly differently depending on infrared wavelengths so that just by controlling the wavelengths, the drug release time can be deliberately chosen. ${ }^{21}$

Nanosilver is engineered for its anti-bacterial properties, and thus is widely found in clothing, children's toys, cosmetics, and cleaning products. $^{22}$ Because nanosilver is believed to be non-toxic, there is little concern over its use in daily products. In fact, nanosilver is the most widely used nanomaterial in production. ${ }^{23}$ One possible problem that researchers have identified relating to nanosilver is that the particles may interfere with DNA

14. Paul C. Sarahan, Nanotechnology Safety: A Framework for Identifying and Complying with Workplace Safety Requirements, 5 NANotechnology L. \& Bus. 191, 192 (2008).

15. Id.

16. Id.

17. Milling is a solid-state process. Robert Dowding \& Delcie Durham, National Materials Advisory Board, National Research Council, Summary of the Workshop on Structural Nanomaterials 3 (National Academy Press 2001), available at http://www.nap.edu/catalog.php?record_id=10253.

18. Gang Han, et al., Drug and Gene Delivery Using Gold Nanoparticles, 3 NANOBIOTECHNOLOGY 40, 41 (2007).

19. Mass. Inst. of Tech., Gold Nanoparticles for Controlled Delivery, ScI. DAILY (Jan. 6, 2009), http://www.sciencedaily.com/releases/2008/12/081231005359.htm.

20. Id.

21. Id.

22. See Higgs, supra note 1.

23. Id. 
replication fidelity and bind with DNA. ${ }^{24}$ There is also a slight concern that the particles may disrupt energy production pathways for cells and cytotoxicity. ${ }^{25}$ Though these effects are considered "non-toxic" by researchers, interference with DNA replication and energy production pathways should be deemed to be severe side effects, regardless of how attenuated.

Carbon nanotubes are cause for the most concern. These microscopic carbon fibers were discovered by researchers in Scotland to be responsible for the "same kind of cancer-causing cellular damage in mice as asbestos." ${ }^{, 26}$ The tiny nanotubes are long-thin fibers, much like asbestos. ${ }^{27}$ Thus, inhaled nanoparticles may penetrate into the lungs causing damage, and studies have documented the adverse health impacts of these tiny particles on rats. ${ }^{28}$ It is possible that the same could occur in humans. Regardless, nanotubes are still used because they conduct heat and transmit electricity extremely well, and have improved strength and hardness over many current materials. ${ }^{29}$ Current applications include high-efficiency chemodelivery systems and super-strong mountain bike handlebars. ${ }^{30}$

Other less common nanomaterials include buckyballs, ${ }^{31}$ diamond nanoparticles, ${ }^{32}$ iron nanoparticles, ${ }^{33}$ and silica nanoparticles, ${ }^{34}$ and each of

24. Nanosilver may directly interact with DNA polymerases, which are necessary for DNA to properly duplicate. Michael Berger, Nanosilver Used in Food Storage Materials Found to Interfere with DNA Replication, NANOWERK (Feb. 19, 2009), http://www.nanowerk.com/spotlight/spotid=9340.php.

25. Id.

26. Elie Dolgin, States Struggle to Deal with Nanotech Health Concerns: Fine Particles Could Damage Cells, MilwaukeE J. Sentinel, June 25, 2008, at A1; see also Kevin Rollins, Nanobiotechnology Regulation: A Proposal for Self-Regulation with Limited Oversight, 6 NANOTECH. L. \& BUS. 221, 224 (2009).

27. Asbestos, U.S. EnVtl. Prot. Agency, http://www.epa.gov/asbestos (last updated June 18, 2010).

28. See Sarahan, supra note 14, at 192-93. See also Rollins, supra note 26, at 224.

29. Sarahan, supra note 14, at 192.

30. Michael Snyder, Indiana's Nanotechnology Revolution - A World Leader?, INSIDE IND. Bus., http://www.InsideIndianaBusiness.com/contributors.asp?id=1235 (last visited Feb. 10, 2010).

31. Buckyballs, aka buckminsterfullerenes, are hollow, spherical molecules made of carbon. Res. AND DeV. of THE U.S. DePT. OF ENERgy, Richard E. Smalley, Buckminsterfullerenes (the Buckyball), and Nanotubes, OfF. OF SCI. AND TeChNICAL INFO. OF THE U. S. DEPT. OF ENERGY, http://www.osti.gov/accomplishments/smalley.html (last visited Feb. 10, 2010).

32. Diamond nanoparticles may have significant uses as drug carriers, nanorobots, and other medical applications. Am. Chem. Soc'y, Easing Concerns about the Toxicity of Diamond Nanoparticles, SCI. DAILY (Jan. 2, 2007), http://www.sciencedaily.com/releases /2007/01/070101113457.htm.

33. Iron nanoparticles may be used in power-transformer cores and magnetic storage media. Lin Guo et al., Iron Nanoparticles: Synthesis and Applications in Surface Enhanced Raman Scattering and Electrocatalysis, 3 J. PHys. CHEM. CHEM. PHYs. 1661, 1661 (2001).

34. Silica nanoparticles are being researched for cancer detection purposes. Detecting Cancer with Silica Nanoparticles, PHYSORG.COM (Sept. 18, 2006), http://www.physorg. com/news77816615.html. 
these may present dangerous risks to humans. ${ }^{35}$ Many of these conclusions are yet to be known due to the slow progress in nanotechnology research.

\section{B. The Issue: Regulating Nanotechnology}

Regulating nanotechnology is a difficult task because the effects of nanomaterials are not completely known. In addition, the concerns of the government, industry professionals, and the public must all be considered. A voluntary regulatory scheme can address these concerns in the short-term while sufficient federal regulations are crafted. As Dr. Landrigan alluded to, the problem of nanotechnology is much like a vicious circle, caused by a lack of knowledge across the board. ${ }^{36}$ The circle starts with the mutual desire to release product improvements onto the market for consumer's enjoyment and companies' profit. $^{37}$ For this to occur, two things must first happen. One, the government has to allow the product onto the market. ${ }^{38}$ Two, consumers have to buy the products to benefit from them. In order for consumers to purchase the product, most need to know, or at least feel, that the product is both safe and effective. Consumers are reassured products are safe based on governmental testing that warrants the products have gone through adequate testing. ${ }^{39}$ In the case of nanotechnology, there are no specific regulations or safety standards because to enact new regulations, the government requires complete information on safety and effectiveness. ${ }^{40}$ As noted, the safety of nanomaterials is yet to be known. ${ }^{41}$ To determine the necessary safety information, companies and universities need research funds. Companies, however, cannot expend mass amounts on research if they are not gaining profits from products on the market. Additionally, much of the important data is collected once the public starts to use the product. $^{42}$ Without regulations, the public is unlikely to support the industry. Without regulations, companies cannot keep producing. Nevertheless,

35. Rollins, supra note 26, at 225.

36. See Part I.

37. See generally Michael Spence, Production Selection, Fixed Costs, and Monopolistic Competition, 43 REV. ECON. STUD. 217, 217 (1976) (providing information on economic analysis).

38. See generally 21 U.S.C. § 301(c) (2006) (Under the Food and Drug Administration's Federal Food, Drug, and Cosmetic Act, products may be required to go through a premarket testing process. Without testing, the product is not allowed on the market.).

39. Jordan Paradise et al., Evaluating Oversight of Human Drugs and Medical Devices: A Case Study of the FDA and Implications for Nanobiotechnology 37 J.L. MED. \& ETHICS 598, 600 (2009).

40. Id at 603-04.

41. Id.

42. See generally David Austin \& Colin Baker, Cong. Budget Off., Econ. AND Budget Issue Brief: Pharmaceutical R\&D AND the Evolving Market for PRESCRIPTION DRUGS (2009), available at http://www.cbo.gov/ftpdocs/106xx/doc10681/1026-DrugR\&D.pdf (In the pharmaceutical industry, important data is collected during clinical trials.). 
without companies producing, the government cannot gain enough information to set regulations. In the case of nanotechnology, the government, consumers and industry all lack adequate knowledge. ${ }^{43}$ This cycle must be broken so the potential of nanotechnology can be realized.

Because nanotechnology is so new, there is an opportunity "for us to get it right from the start." ${ }^{, 4}$ Thus, because there are currently no specific regulations in place for nanotechnology, new regulations can be set to both encourage production using nanomaterials to their fullest potential while also ensuring the public is safe from possible harms. ${ }^{45}$ Focusing too much on either issue is unlikely to be sufficient. As discussed later in this Note, there is no applicable regulatory scheme into which nanoparticles "fit." Though existing regulations are currently applied to the nanotechnology industry, none are sufficient to achieve public health reassurance and continue to incentivize innovation. ${ }^{47}$ If a new regulatory scheme is to be crafted from scratch, now is the time to be cognizant of all relevant considerations, rather than simply tweaking the already pre-existing regulations. To "get it right from the start" will undoubtedly take time and resources that many innovative companies may not be capable of expending. ${ }^{48}$

Not only does creating a new regulatory scheme take time, but the current debate over how to structure the regulations or whether regulations are even needed in the first place, causes delay. ${ }^{49}$ Thus, the process is moving slowly toward a final decision on whether, and how, to regulate. However, negative experiences with materials such as $\mathrm{CFCs},{ }^{50} \mathrm{PCBs},{ }^{51}$ and asbestos ${ }^{52}$

43. James Yeagle, Nanotechnology and the FDA, 12 Va. J.L. \& TECH. 6, 65 (2007).

44. See Regulating Nanotechnology, supra note 13.

45. Id.

46. See Paradise et al., supra note 7.

47. Id.

48. Robin Wilson, Nanotechnology, The Challenge of Regulating Known Unknowns, 34 J.L. MED. \& ETHICS 704, 711 (2006) (highlighting the low amount of capital for many nanotech start up companies).

49. See Higgs, supra note 1.

50. Chlorofluorocarbons ("CFCs") are catalytic agents in ozone depletion. However, they were originally ideal for many applications because they are non-toxic to humans, nonflammable, and non-reactive with other chemical compounds. CIESIN Thematic Guides: Chlorofluorocarbons and Ozone Depletion, CENTER FOR INT'L EARTh ScI. INFO. NeTwork ("CIESIN"), http://www.ciesin.org/TG/OZ/cfcozn.html (last visited Feb. 10, 2010).

51. The production of Polychlorinated Biphenyls ("PCBs") was banned in 1979 due to their high toxicity. However, they were originally ideal for electrical, heat transfer, hydraulic, plastic, and paint plasticizer applications because of their non-flammability, chemical stability, and high boiling point. Polychlorinated Biphenyls, U.S. Envtl. Prot. Agency, http://www.epa.gov/epawaste/hazard/tsd/pcbs/index.htm (last updated Dec. 6, 2010).

52. Asbestos' microscopic fibers that are released into the air can be inhaled into the lungs, causing significant health problems. Though the use of asbestos is now banned, the mineral fiber was originally used for many years in building construction materials and as a fire retardant. Initial testing of asbestos demonstrated its fiber strength and heat resistant properties before negative health effects were discovered. See Asbestos, supra note 27. 
suggest it would be wise to discover and address any potential negative health and environmental effects before the use of nanomaterials becomes widespread. The problems caused by asbestos have become infamous in the United States. Asbestos, originally a breakthrough technology, had risks that were not realized until many years later when cases of mesothelioma $^{53}$ emerged in people who spent substantial time around products containing asbestos. ${ }^{54}$

To add to the confusion, not only are the effects of nanotechnology unknown, but also the NNI only has an incomplete inventory of what nanomaterials are even in production and use. ${ }^{55}$ As products are released onto the market without sufficient regulations the innovative company is not who society should be worried about. While an uncertain regulatory scheme may lead companies to choose between innovation and facing uncertain risks (and ultimately uncertain liability), consumers are in danger of being harmed by unsafe and untested products. Many consumers are unaware that some of the products they use daily may contain nanoparticles. ${ }^{56}$ Something can be done in the meantime, however. Voluntary regulations can serve to foster innovation, work toward a proper regulatory scheme, and calm consumer apprehensions regarding products containing nanotechnology. A voluntary regulatory scheme, such as the one proposed in this Note, would not replace eventual federal regulations. Instead, voluntary regulations can be used to fill the gap, while waiting to decide which existing federal regulations to apply, or whether to craft new regulations.

\section{BACKGROUND INFORMATION}

\section{A. Nanotechnology's Possible Problems}

Though much speculation exists that nanomaterials are harmful, the full picture as to what extent of harm nanomaterials may cause has yet to be drawn. A voluntary regulatory program can incentivize research into the possible problems associated with nanomaterials.

53. Most people with mesothelioma worked with, or lived near, asbestos. Mesothelioma is caused when cancer cells are found in the sac lining the chest, the lining of the abdominal cavity, or the lining around the heart. As little as two to three months of exposure of asbestos can cause mesothelioma. Malignant Mesothelioma, NAT'L CANCER Inst., http://www.cancer.gov/cancertopics/types/malignantmesothelioma (last visited Feb. 10, 2010).

54. Many of those affected by asbestos were factory workers who worked producing the asbestos-containing products, and those that lived near the industries. See Asbestos, supra note 27.

55. See Nastassja Lewinski, Nanomaterials: What are the Environmental and Health Impacts?, Chem. Eng. Progress, Dec. 2008, at 37. See generally Education and Workforce Needs, NAT'L NANOTECHNOlOGY InITIATIVE, http:/www.nano.gov/html/society/ Education.html (last visited Jan. 5, 2011).

56. See Higgs, supra note 1. 
Even now, there are concerns being raised about the hazards of nanotechnology. ${ }^{57}$ However, safety groups argue that the reason these have not been quickly addressed is that "[d]ollar signs have blotted out the warning signs." ${ }^{58}$ Because it is expensive to research possible effects of a new technology, the warnings are ignored in order for profits to be achieved. For a study to be conducted effectively, large population samples must be used, as well as trials that span long periods of time. ${ }^{59}$ According to nanotechnology special interest groups, there is a sense of urgency for innovative companies to release products containing nanomaterials. ${ }^{60}$ It has become a "modern-day gold-rush-forget precaution, get to production . . . . We might not know for certain whether nanotech will make you sick, but industry knows it can certainly make you rich ...."

The potential ability of nanoparticles to enter cells because of their small size is what makes them toxic. ${ }^{62}$ In addition, nanomaterials have a larger surface area to volume ratio than many particles, which leads to greater reactivity. ${ }^{63}$ Initial studies conducted by the EPA have shown that certain nanomaterials have the ability to pass through cell membranes or cross the blood-brain barrier in ways that larger scale materials cannot. ${ }^{64}$ Currently, these adverse health effects have been documented in both mice and fish. ${ }^{65}$ Scientists have conducted testing on fish to ascertain toxicity data. ${ }^{66}$ The nanoparticles affected the gills of the fish, ${ }^{67}$ which suggests that as the size and shape of nanoparticles can penetrate gills, they may also be able to penetrate human skin, though it is too early to tell at this point. ${ }^{68}$ Research also seems to suggest that the different shapes of nanoparticles are

57. John Monica Jr. et al., Preparing for the Future Health Litigation: The Application of Products Liability Law to Nanotechnology, 3 NANOTECH. L. \& BUS. 54, 54 (2006).

58. Id. at 55 .

59. See Benjamin Zycher et al., Center for Medical Progress at the Manhattan Institute, No. 6, The Truth About Drug Innovation: Thirty-Five Summary Case Histories on Private Sector Contributions to the Pharmaceutical SCIENCE (2008), available at http://www.manhattan-institute.org/pdf/mpr_06.pdf.

60. Monica et al., supra note 57, at 55.

61. Id.

62. See Liz Kalaugher, Nanoparticle Size Affects Uptake by Cells, NANOTECHWEB .ORG (Mar. 17, 2006), http://www.nanotechweb.org/cws/article/indepth/24455.

63. Reactivity increases where there is more space for a second molecule to bind. As the surface area increases, without increasing the volumic weight, the potential space for a second molecule to bind increases. See generally K. Kuo \& H. Marsh, Active Surface Area on Carbon Reactivity, 34 Amer. Chem. Soc., Div. Fuel Chem. Preprints 153 (1989), available at http://www.anl.gov/PCS/acsfuel/preprint\%20archive/Files/34_1_DALLAS_0489_0153.pdf.

64. Sarahan, supra note 14, at 192-93.

65. Rick Weiss, Nanoparticles Toxic in Aquatic Habitat, Study Finds, WASH. Post, Mar. 2, 2004, at A2.

66. See Effects of Nanotechnology on Health and Environment, THE MED. News (Jan. 30, 2007), http://www.news-medical.net/news/2007/01/30/21628.aspx.

67. Id.

68. Id. 
responsible for the various adverse affects. ${ }^{69}$ Accordingly, University of Florida toxicologist, David Barber, noted that if different effects are felt every time a nanoparticle changes shapes, the regulatory burden will be great. $^{70}$

Additionally, in August 2009, the deaths of two female factory workers in China were allegedly linked to adverse effects of nanotechnology at a factory that produced paint containing nanomaterials. ${ }^{71}$ The two girls died from lung damage similar to that seen in asbestos-related mesothelioma victims, while seven others suffered severe effects. ${ }^{72}$ The precise reason for the deaths has not yet been released, but the possibility that nanoparticles could cause these kinds of effects is cause for alarm.

An across-the-board policy or regulatory scheme does not make sense for nanotechnology. ${ }^{73}$ Each type of nanomaterial has different uses and structures that require specific consideration. In addition, as nanomaterials change size (as a macro molecule is transformed to the nano-scale) the properties of the material change even when the composition stays the same. ${ }^{74}$ These considerations make any hasty regulatory decision unwarranted. However, a purely precautionary approach should not be taken either because a "better safe than sorry" outlook forces innovative companies to come to a standstill, decreasing innovation and possibly forcing them out of business. ${ }^{75}$ Accordingly, a voluntary regulatory scheme may ease the feeling that regulations should be established without due thought. The industry can regulate itself in the interim and ideally gather information for the federal government to make the permanent regulatory decision.

\section{B. Current Outlook}

Progress in the nanotechnology field depends on "societal interest, available funding, and ultimately public confidence" in the technology. ${ }^{76}$

\section{Available Funding for Nanotechnology}

It appears that governmental interest and funding is in full force to

69. Id.

70. Id.

71. See Timothy Malloy, Nanoparticles Potentially Linked to Factory Worker Deaths in China, Legal Planet the Envtl L. And Pol'y Blog, BerkeleyLaw/UCla Law (Aug. 20, 2009), http:// legalplanet.wordpress.com/2009/08/20/nanoparticles-potentially-linked-tofactory-worker-deaths-in-china/.

72. Id.; see also Xu Chao, Trail of Death Leads Doctors to Nanoparticles, CAJING MAG. (Sept. 24, 2009), http://english.caijing.com.cn/2009-09-24/110259731.html.

73. See Dolgin, supra note 26.

74. See generally Nanofacts, NANOMATERIAls COMPANY, http://www.nano materialscompany.com/nanofacts.html(last visited Jan. 5, 2011).

75. Wilson, supra note 48 , at 710 .

76. See Paradise et al., supra note 7, at 411. 
achieve the NNI's vision of an industrial and technological revolution. ${ }^{77}$ United States federal funding for nanotechnology research and development "has increased from approximately $\$ 464$ million in 2001 to nearly $\$ 1.5$ billion for the 2009 fiscal year.," 78 In fact, the number of researchers in the field of nanotechnology is expected to increase ten thousand percent in the next fifteen years. ${ }^{79}$ By 2014, it is estimated that products containing nanotechnology will represent $\$ 2.6$ trillion in manufactured goods and nearly fifteen percent of global manufacturing. ${ }^{80}$ Nanotechnology is projected to be a major part of not only the future of the United States, but of the global market as a whole. It is more important than ever to construct a regulatory scheme that encourages innovation and will protect potential consumers from adverse effects.

\section{Societal Interest in Nanotechnology}

Nanotechnology has the ability to revolutionize many commercial and medical industries. The principal use of existing nanotechnology is drug delivery applications. ${ }^{81}$ Using nanotechnology to deliver drugs to the body provides for increased drug efficacy and an increased ability to target specific cells. ${ }^{82}$ If the projections regarding the benefits of nanotechnology are true, neither innovative companies nor consumers will have a desire for production to come to a complete halt.

New developments are made every day in the field of nanotechnology. For example, Chad Mirkin from the Massachusetts Institute of Technology found a way to use nanomaterials to identify "low concentrations of disease-signifying molecules." 83 Accordingly, despite large data gaps, drug companies are not easily persuaded to stop research and production of

77. See Funding, NAT'L NANOteChNOlogy Initiative, http://www.nano.gov/ $\mathrm{html} /$ about/funding.html (last visited Oct. 23, 2010) (listing the 2011 NNI budget at $\$ 1.8$ billion dollars).

78. Rollins, supra note 26, at 222.

79. $I d$.

80. Id.

81. Id.; see also Majeti N.V. Raul Kumar, Nano and Microparticles as Controlled Drug Delivery Devices, 3 J. PhARM. PhARM. SCI. 234 (2000) (stating that nanotechnology is used in drug-delivery applications by attaching a drug to a nanoparticle which allows scientists to use the favorable properties of nanoparticles to target specific cells).

82. Rollins, supra note 26, at 222; see also Drug Action: Drug Dynamics: Merk Manual Home Edition, MERK \& CO., INC., http://www.merck.com/mmhe/sec02/ch012/ ch012c.html (last updated Nov. 2007) ("Efficacy is the capacity to produce an effect. In a drug context, efficacy is the ability of a drug-receptor complex to produce a functional response. The small size of nanoparticles, along with the increased surface area to volume ratio makes nanoparticles ideal to bring about these sought after effects.").

83. See Press Release, Lemelson-MIT Program, World-Renowned Nanotechnology Expert Proves There is Big Potential in the Smallest of Matter (June 24, 2009), available at http://web.mit.edu/Invent/n-pressreleases/n-press-09LMP.html. 
nano-containing products completely, and government is reluctant to impose regulatory requirements. ${ }^{84}$

Until all the potential effects of nanotechnology are known, regulators are unclear on how to move forward with nanotechnology regulation. ${ }^{85}$ Accordingly, a framework needs to be in place that allows for flexibility. Innovation and regulation need to co-exist in the interim until a concrete federal regulatory scheme is developed. A flexible scheme such as a voluntary program can allow innovators to weigh the benefits and costs of production before research is complete. At the same time, a voluntary scheme can aid regulators in choosing the proper regulations for the long-term. Implementing broad regulations immediately can start the process towards refinement and narrowing of the regulatory scope over time.

\section{Public Confidence and Perceptions}

For the full effect of nanotechnology to be realized, the public must perceive it to be useful and safe. According to Alan Gotcher, CEO of Altair Nanotechnologies, opinions regarding nanotechnology may be framed from a position of "uninformed fear," resulting in the presumption that nanotechnology is bad. ${ }^{86}$ Gotcher's opinion may be indicative of a general attitude in society that emerging technologies always get ahead of ethical, social, and legal reflections. ${ }^{87}$ The new technology in many cases has to prove itself before it is widely accepted.

Articles such as "Mama, Dada, Nano? Subparticles may be Toxic for Kids" impute fear into the public. ${ }^{88}$ The above article claims that nanomaterials are present in many household products, and may have negative effects on children. ${ }^{89}$ In fact, it is hard for consumers to know whether an item contains nanoparticles as many products do not use nanotechnology as their marketing tool. Nanoshop.com is one example of a website that is devoted solely to nano-containing products. ${ }^{90}$ Nanoshop.com sells glass, metal, and concrete treatment products, all containing various nanotechnology. ${ }^{91}$

84. See Brindell, supra note 11 , at 74 .

85. See id.

86. See Regulating Nanotechnology, supra note 13.

87. $I d$.

88. See Higgs, supra note 1.

89. Id.

90. See generally NANOSHOP, http://www.nanoshop.com (last visited Oct. 25, 2010). See also Ann Fernholm, Consumers Not Always Aware of Presence of Nanotechnology, S.F. Chron., May 12, 2008, at D3, available at 2008 WLNR 8904538 (stating that "customers can find a softener for baby cloths and underwear containing nanosilver, in addition to antimicrobial paint and a shoe deodorizer.").

91. See, e.g., NANOShop, supra note 90. 
Public alarm and strong concerns regarding new technologies have become known as "Social Shocks." 92 Social institutions grapple with the problem for varying amounts of time while "papers on effects increase[] in the technical literature."93 Astoundingly, the delay between innovation and social acceptance, on average, can be as much as one to two decades. ${ }^{94}$

News stories are not only increasingly concerned with the effects of nanotechnology, but are also critical of the government's regulatory abilities, as the number of U.S. risk-focused stories rose fifty-eight percent from 2005-2006 alone. ${ }^{95}$ This is important as many consumers gather pertinent information from both the local and national media. The question posed by news stories is whether the government is even up to the job of nanotechnology oversight--whether twentieth-century regulations are ready for a twenty-first-century technology.

\section{Federal REgulations}

Current federal regulations are insufficient to regulate nanotechnology. As it takes time to design a new regulatory scheme, a voluntary regulatory program can step in to allow industry to regulate itself in the interim.

\section{A. Existing Debate Concerning Regulation}

The current debate around nanotechnology centers on whether existing regulations set by agencies such as the FDA and the EPA are sufficient to handle the new technology. ${ }^{96}$ Prominent figures in nanotechnology research and regulation readily disagree on this point. Neil Desai, Ph.D., Vice President of Research and Development at Abraxis Biosciences, says that there are no new or unique toxicities involved in the use of nanoparticles to deliver drugs. ${ }^{97}$ Therefore, the regulations in place are sufficient. However, Piotr Grodzinski, Ph.D., Director of Nanotechnology cancer programs at the NCI Alliance for Nanotechnology in Cancer, disagrees. ${ }^{98} \mathrm{He}$ believes the "multifunctional properties of some nanoparticles . . . used to deliver both diagnostics and treatments," coupled with the high level of in-

92. Igor Linkov et al., Nano Risk Governance: Current Developments and Future Perspectives, 6 NANotechnology L. \& Bus. 203, 206 (2009).

93. Id.

94. Id.

95. See Press Release, The Pew Charitable Trust, Nanotechnology Regulators Make News (Dec. 18, 2007), available at http://www.pewtrusts.org/news_room_detail .aspx?id=32490.

96. Mark McCarty, Many Calls for New Nano Regs Not Likely to be Heeded Soon, MedicAl Device DAILY, October 13, 2006, available at 2006 WLNR 17855392.

97. Id.

98. Id. 
novation in the nanotechnology sector, are important considerations. ${ }^{99}$ Thus, according to Grodzinski, a new regulatory scheme is needed. ${ }^{100}$ Though these types of debates over a proper regulatory scheme have continued since 2001, no conclusion has been reached and the debate drags on.

If Desai and Grodzinski are indicators, it seems much of the line in this debate is drawn between researchers and industry professionals. Researchers push for new regulations because they realize the potentially unique properties of nanotechnology, and are driven from a profit-making perspective. On the other hand, those who work for innovative companies will likely prefer to use existing federal regulations and adapt them to nanotechnology. While innovative companies ideally prefer no regulation, this is not a viable choice. Federal regulations are viewed by the innovative company as reliable because the company knows what each agency looks for, as they have dealt with the regulations in the context of other products. ${ }^{101}$ The company, therefore, does not have to learn new terms and requirements. Instead, they simply have to apply those standards to nanotechnology. Additionally, merely modifying existing regulations is likely to end the debate more quickly.

The existing regulations being considered include the EPA Toxic Substances Control Act ("TSCA"), ${ }^{102}$ the FDA Federal Food, Drug, and Cosmetic Act ("FDCA"), ${ }^{103}$ Occupational Safety and Health Administration ("OSHA") standards, ${ }^{104}$ the Consumer Products Safety Act ("CPSA"), ${ }^{105}$ and combinations of these.

\section{Environmental Protection Agency: Toxic Substances Control Act}

The EPA's TSCA regulates chemical substances that may be dangerous to the environment. ${ }^{106}$ The TSCA has the ability to regulate new chemical substances; that is, there are separate regulations for new chemicals beyond those listed in the existing chemical inventory. ${ }^{107}$ Some scholars believe that this "new chemical" provision can be used to regulate products containing nanoparticles. ${ }^{108}$ However, Andrew Maynard, science advisor

99. Id.

100. Id.

101. For example, if the Toxic Substances Control Act ("TSCA") is used to regulate nanotechnology, companies will be familiar with the provisions as the TSCA regulates other known hazardous chemicals the company may produce. See generally 15 U.S.C. $\S \S 2601-29$ (2006).

102. Id.

103. See generally 21 U.S.C. $\S \S 301-99$ (2006).

104. See generally 29 C.F.R. $§ 1910$ (2010).

105. See generally 15 U.S.C.A. $\S \S 2051-89$ (West 2010).

106. See 15 U.S.C. $\S \S 2601-29$.

107. 15 U.S.C. $\$ 2605$ (2006).

108. News Release, EPA Foregoes Opportunity to Improve Nanotechnology Oversight, Woodrow Wilson Int'l Ctr. for Scholars (July 12, 2007), available at 
for the Project on Emerging Nanotechnologies, stated that the approach taken by the EPA ignores research that states "different nanostructures with the same molecular identity present different hazards." 109 The question to be answered is whether nanoparticles can actually be considered new chemicals or whether they are completely different and, thus, whether the existing method of TSCA regulation is sufficient. For example, TSCA will regulate only if the molecular identity of a particular nanoparticle is different from the molecular identity of the macroparticle of the same material that is on TSCA's inventory list. ${ }^{110}$

\section{Food and Drug Administration: Federal Food Drug and Cosmetic Act}

The FDA generally regulates on a product-by-product basis, subjecting each new product to rigorous testing before it is approved to be released on the market. ${ }^{111}$ Products are "often categorized according to the mode of action, and uses intended by the manufacturer."112 The FDCA regulates new drugs through a "pre-market testing and approval process," along with meeting "safety, efficacy, and manufacturing standards." mined to be of a higher-risk must go through an application process showing they are both safe and effective before they can be put on the market, while lower-risk products may be marketed if shown to be substantially similar to a product already on the market. ${ }^{114}$ A report released by the Nanotechnology Task Force concluded that the FDA need not develop a new framework or special regulations for nanotechnology because current FDA regulations are adequate. ${ }^{115}$ However, there are other considerations, such as provisions that allow certain products to skip the pre-market testing process, that make some believe the FDA's regulations are inadequate. ${ }^{116}$

\section{Occupational Safety and Health Administration}

OSHA regulations are in place to protect employees that handle dangerous materials. ${ }^{17}$ The General Duty Clause behind the regulations, imposes on an employer the duty to maintain "a place of employment . . . free from recognized hazards that are causing or are likely to cause death or se-

http://www.nanotechproject.org/process/assets/files/5979/07120nanotechnology_epatsca_pr. pdf.

109. Id.

110. See Brindell, supra note 11, at 75; see also 15 U.S.C. $\S \S 2601-29$.

111. See 21 U.S.C. \$ 301-99 (2006).

112. See Paradise et al., supra note 7 , at 403.

113. Id.

114. Id. at 403-04.

115. $I d$. at 404 .

116. For example, under the Federal Food, Drug, and Cosmetic Act, there is no premarket testing for cosmetics. Wilson, supra note 48, at 707.

117. See generally 29 C.F.R. $\S 1910$ (2010). 
rious physical harm to his employees." ${ }^{118}$ Because the hazard must be recognized to impose a duty on the employer, nanotechnology creates problems for OSHA regulations as the possible hazards have not yet been determined. Thus, the regulations seem to imply that no safety requirement has to be met until concrete hazards are identified. Specifically, OSHA regulates on a product-by-product basis, where each product requires different procedures and reporting requirements, and allows different levels of exposure to employees. ${ }^{119}$ Nanotechnology is not listed as a category under "Toxic and Hazardous Substances."120 Further, "recognized hazard" goes to the knowledge of the employer, ${ }^{121}$ or in the absence of actual knowledge, to the standard of knowledge in the industry. ${ }^{122}$ In the case of nanomaterials, a one-time assessment of risks will likely not be sufficient. Risks are likely to change over time. For example, many remember that the harsh reality of asbestos did not become known until many years after it had been put to use and hailed as a breakthrough in technology. ${ }^{123}$

\section{Consumer Product Safety Act}

The CPSA focuses on protecting consumers from unreasonable risks of injury associated with consumer products. ${ }^{124}$ Under the CPSA, the Consumer Product Safety Commission ("the Commission") "may ban products that create an "unreasonable risk of injury" when "no feasible consumer product safety standard" can adequately address that risk.", "Because the Commission's regulatory authority is generally limited to consumer products not specifically regulated by another statute, its authority would not extend to many nanotechnology applications, including foods, drugs, cosmetics, pesticides, and automobiles," ${ }^{126}$ all of which are regulated under other statutes. ${ }^{127}$ Thus, though the purpose of the CPSA focuses on increasing consumer safety where federal regulations are inadequate, ${ }^{128}$ the limiting language greatly stifles this purpose.

118. 29 U.S.C. § 654(a)(1) (2006); see also Sarahan, supra note 14, at 194-96.

119. See generally 29 C.F.R. § 1910 (for example, subpart Z of 29 C.F.R. § 1910 lists specific toxic and hazardous substances such as asbestos (29 C.F.R. $\S 1910.1001)$ and lead (29 C.F.R. § 1910.1025)).

120. See 29 C.F.R. $§ 1910$, at subpart z.

121. See 29 C.F.R. $\S 1903.1$ (2010).

122. See Ethel Alston, What is "Recognized Hazard" Within the Meaning of General Duty Clause of Occupational Safety and Health Act (29 U.S.C.A. $\S 654(a)(1))$ ?, 50 A.L.R. Fed 741 (1980).

123. Wilson, supra note 48 , at 710 .

124. Albert C. Lin, Size Matters: Regulating Nanotechnology, 31 HARV. EnvtL L. Rev. 349, 369 (2007).

125. See id. at 369 (quoting 15 U.S.C. $\S 2057$ (2006)).

126. Id.

127. See, e.g., Toxic Substances Control Act, 15 U.S.C. $\S ~ 2601-29$ (2006); Federal Food, Drug, and Cosmetic Act, 21 U.S.C. $\S \S 301-99$ (2006).

128. See 15 U.S.C. $\S 2051$ (2006). 


\section{Other Sources}

There are other non-federal sources that may be capable of regulating nanomaterials; however, none of these are particularly suited to deal with the needs of nanotechnology. The International Council on Nanotechnology ("ICON") is working on gathering and compiling information on nanotechnology. ${ }^{129}$ ICON is an international organization "whose mission is to develop and communicate information regarding potential environmental and health risks of nanotechnology ....,130 ICON seeks to foster "risk reduction while maximizing [the] societal benefit[s]" of nanomaterials. ${ }^{131}$ This information gathering is useful, but ICON lacks any actual authority for enforcement. Thus, no companies are forced to release information to ICON.

In a similar manner to what is proposed in this Note, the EPA previously convened a voluntary industry program known as the Nanoscale Materials Stewardship Program ("NMSP"). ${ }^{132}$ The NMSP sought to encourage those in the nanotechnology industry to provide the agency, on a voluntary basis, with scientific information about risk management practices. ${ }^{133}$ The NMSP invited participating companies to voluntarily share existing data and discuss a program designed to develop new data for the long-term. ${ }^{134}$ For a voluntary program to enjoy a maximum amount of participation, incentives must be given. This Note's proposed voluntary program would incentivize the maximum amount of companies to participate and will seek to gather new information and encourage greater levels of research rather than merely accepting reports of existing data.

\section{B. Why Federal Regulations for Debate?}

The current debate around nanotechnology regulation centers on possible federal action, rather than state action. Both avenues have costs and benefits, but the benefits of federal action for nanotechnology outweigh state benefits for long-term regulation. However, the benefits of state action suit short-term goals such as a voluntary regulatory program. The case

129. See generally Int'l Council on Nanotechnology, Rice UnIVERSITY, http://www.icon.rice.edu (last visited Oct. 26, 2010).

130. Int'l Council on Nanotechnology, Mission and Strategy, Rice University, http://icon.rice.edu/about.cfm?doc id=4379\#Mission (last visited Oct. 26, 2010).

131. Id.; see also Kristen Kulinowski \& Matthew Jaffe, The GoodNanoGuide: A Novel Approach for Developing Good Practices for Handling Engineered Nanomaterials in an Occupational Setting, 6 NANotechnology L. \& Bus. 37, 38-41 (2009) (detailing the creation of "The GoodNanoGuide," an internet site where companies can share occupational practices for safe handling of nanomaterials).

132. Nanoscale Materials Stewardship Program, U.S. Envtl. Prot. Agency, http://www.epa.gov/opptintr/nano/stewardship.html (last updated Apr. 22, 2010).

133. See id.

134. See id. 
for government regulation rests on three assumptions:

(1) Public regulations are both democratic and fair because governments choose to openly respond to public concerns, and not private interests.

(2) Governments have the ability to correctly estimate the cost of externalities and then propose systems to compel firms to internalize these regulations.

(3) The state is capable of enforcing regulations, and firms will tend to adhere to the law. ${ }^{135}$

Thus, federal regulations are likely to be the primary mechanism for compelling companies to internalize costs that they would otherwise externalize. Federal regulations alter a company's cost calculus, forcing them to include externality costs when deciding on production outputs, budgets, etc. It is also easier for governmental agencies to assess risks over a large area of research and then gather information accordingly. The federal government not only has larger amounts of funding and resources than the states do, the federal government can also implement across-the-board policies, rather than having each state set its own individual policy. This allows for common accounting so all data may be effectively compiled. For instance, the National Institute of Occupational Safety and Health ("NIOSH"), a federal agency, has identified ten critical topic areas that need to be addressed with regard to knowledge gaps in nanotechnology research. ${ }^{136}$

The question that undoubtedly comes to mind, is why not regulate nanotechnology on a state-by-state basis instead of federally? The answer comes from examining the costs and benefits of using state regulations. Imposing regulations on a state-by-state basis could hurt local state businesses if surrounding states have lesser regulations. Harsher regulations equal higher costs, which put one state's innovative companies at a relative disadvantage to another's. In states that have greater regulations, companies would have to expend more resources to comply with the regulations and thus charge higher prices to make up for those costs. This would hurt one state's competitive balance with surrounding states that have less stringent policies.

135. See Aseem Prakash \& Matthew Potoski, Collective Action Through Voluntary Environmental Programs: A Club Theory Perspective, 35 PoL'Y STUD. J. 773, 775 (2007).

136. Nat'l Inst. of Occupational Safety and Health Educ. and Info. Division, Nanotechnology: 10 Critical Topic Areas, Centers for Disease Control and Prevention, http://www.cdc.gov/niosh/topics/nanotech/critical.html (last updated Sep. 22, 2010) (The ten critical topic areas identified by NIOSH include fire and explosion safety, exposure assessment epidemiology and surveillance, and toxicity and internal dose). 
Federal regulations make sense as a logical method of efficiently monitoring and controlling the nanotechnology industry, because nanotechnology is a technical field where there are relatively few experts. Accordingly, concentrating these experts at one federal level rather than dispersing them among the states is more efficient. Terry Davies, a senior fellow at the think tank, Resources for the Future, noted that "a lot is changing at the federal level, but there are a lot of problems . . . . So, there's no question that there's a lot of room for states to take initiative . . .."137 Meanwhile, gaps in data "are forcing unprepared state and local governments to bear the brunt of regulating the new technology's potentially hazardous risks . . . ."138 Additionally, though discussion is focused at the federal level, "federal regulations charge a lot of key statutes to the states." 139 However, state programs are effective in other ways. States can focus on individual state concerns and priorities in research and regulation. In addition, state regulations are more accessible for change by consumers and companies while federal regulations tend to be more inelastic.

Some state and local entities have already decided to take nanotechnology into their own hands. Surprisingly, it seems these initiatives have been successful. Berkeley, California, and Cambridge, Massachusetts, both have local ordinances that address nanotechnology, the first of their kind. ${ }^{140}$ Both require companies to report products that contain nanoparticles, and while Berkeley's reporting is mandatory, Cambridge's reporting is voluntary. ${ }^{141}$ Berkeley's first local nanotechnology ordinance was passed in December of $2006 .^{142}$ The nanoparticle ordinance adds a nanoparticle health and safety disclosure requirement to already existing mandatory inventory and safety plans required from companies. ${ }^{143}$ Worry has arisen in Berkeley because the ordinance presumes high toxicity. ${ }^{144}$ Thus, unless proven otherwise by the innovative company, the nanoparticle products will be deemed dangerous. Additionally, in the future, there exists the problem of inconsistent requirements around the country if many conflicting local ordinances are passed.

Cambridge, Massachusetts, has addressed the concern that strict regulations stifle innovation. Cambridge was the first U.S. city to regulate re-

137. See Dolgin, supra note 26.

138. Id.

139. Id. (quoting Maria Powell, environmental scientist at the University of Madison-Wisconsin's Nanoscale Science and Engineering Center).

140. See Higgs, supra note 1.

141. Id.

142. Matthew Heartney \& John Carlton, City of Berkeley Begins Implementation of Nanotechnology Ordinance, 19 InTELL. Prop. \& TeCH. L. J. 18, 18 (2007).

143. See Rick DelVecchio, Berkeley Considering Need for Nano Safety, S.F. CHRon., Nov. 24, 2006, at A1.

144. Id. 
combinant DNA research and is now a leading biotech research center. ${ }^{145}$ Thus, even if strict local regulations are passed, evidence suggests innovation will not necessarily be stifled.

Wisconsin is the only state that has a nanotechnology working group. ${ }^{146}$ The group is comprised of several Wisconsin governmental agencies including the Department of Natural Resources. ${ }^{147}$ The Wisconsin legislature is contemplating a mandatory registry that would inventory the nanomaterials being made rather than putting restrictions on their use, and the state seems concerned with ensuring the registry does not stifle innovation. ${ }^{148}$ Currently, the group is outlining nanotechnology benefit and risk data gaps and ways to proactively address them. ${ }^{149}$ Likely, the regulatory registry will be similar to that of Berkeley, California.

Not only are there pros and cons to the many different federal regulations that can be used to regulate nanotechnology, there are pros and cons between choosing the federal government or the states to do the regulating. For long-term efficiency, federal regulations are likely the best choice as federal regulations seek to find a cohesive solution for a large class of products. However, reaching a cohesive and effective federal solution will take time, and states could benefit immediately from state-specific regulation. Thus, while the nanotechnology industry awaits federal regulations, a state voluntary program can be implemented.

\section{Problems with Existing Regulations-Short-term and Long-term}

There are several problems with using existing federal mechanisms to regulate nanoparticle products. Thus, to adequately regulate nanotechnology, a new federal scheme may need to be crafted. Because federal regulations are already established, they do not allow room for flexibility. Therefore, it must first be considered whether any of the existing regulations will work as they currently stand. As noted previously, the TSCA would likely regulate nanomaterials as "new" materials. ${ }^{150}$ If nanocontaining technologies and products cannot be considered new, the general consensus is that they do not fit within any other categories in the TSCA, and industry has often taken the position that this means they cannot be ef-

145. See Hiawatha Bray, Cambridge Considers Nanotech Curbs: City may Mimic Berkeley Bylaws, Boston GLOBE, Jan. 26, 2007, at C1, available at 2007 WLNR 1584801.

146. See Dolgin, supra note 26. See generally Intergovernmental Nanotechnology Working Group, UNIVERSiTy OF Wisconsin-MADison NANOSCALE SCIENCE AND ENGINEERING CENTER, http:/www.nsec.wisc.edu/NS--Nugget.php?ID=42 (last visited Feb. $16,2010)$.

147. See Intergovernmental Nanotechnology Working Group, supra note 146.

148. See Dolgin, supra note 26.

149. Id.

150. See supra Part III.A.1. 
fectively regulated under the TSCA. ${ }^{151}$ Many nanoparticles are synthesized from their macro-counterparts. ${ }^{152}$ Accordingly, the inherent composition of nanoparticles is not new. Rather, the only thing new about nanomaterials is their size.

If FDA regulations are utilized, it is likely that some products containing nanotechnology would be put on the market without extensive testing. For example, cosmetics are never subjected to pre-market testing by the FDA. ${ }^{153}$ In addition, it is unlikely that the agency would require a showing of adequate testing by the innovative company if certain conditions are first met. Many products that go through FDA testing are not required to submit to extensive pre-market testing first. ${ }^{154}$ This is the case if the product is substantially similar to a product already on the market. ${ }^{155}$ This exception allows for more competition, better use of FDA resources, and supposedly more innovation. However, because we do not know the hazards of nanomaterials, and because nanomaterials come in many sizes and levels of reactivity, it would not be safe to allow inadequately tested nanoparticle products onto the market without extensive pre-market approval. Additionally, because many nanomaterials have macro-counterparts, the FDA would unlikely submit those products to more rigorous testing, assuming they behave similarly.

Another concern with using the current FDA regulations is whether nanomaterials actually act like any other product on the market. Some have argued that there is no need for a product to go through testing when the only difference between it and a product already on the market is the use of nanotechnology. ${ }^{156}$ This assumes that the nano-product will perform the same as the existing product. In reality, it is often unknown whether using nanomaterials instead of the relevant macro-counterpart will create a different reaction. Seemingly, the fear stems from the increased surface area to volume ratio, which while optimal for greater reactivity of nanomaterials, may come with unwanted side effects that have not yet been readily understood.

The CPSA is limited to consumer products not specifically regulated by another statute. ${ }^{157}$ Thus, its authority may not extend to many nanotechnology applications because they could, in theory, be regulated by other

151. Jeffrey Rudd, Regulating the Impacts of Engineered Nanoparticles under TSCA: Shifting Authority from Industry to Government, 33 CoLuM. J. ENVTL. L. 215, 225 (2008).

152. Lynn Bergeson, TSCA and Engineered Nanoscale Substances, NANOTECHNOLOGY L. \& Bus., March 2007, at 51, 53.

153. Wilson, supra note 48 , at 708.

154. See generally 21 U.S.C. § 301-99 (2006).

155. Id.

156. See Gregory Mandel, Nanotechnology Governance, ALA. L. REV. 1323, 1357 (2008).

157. See discussion, supra Part III.A.4. 
federal regulations. ${ }^{158}$ Additionally, OSHA regulations are useful for employee safety, but do not attempt to protect the public once the product reaches the market. ${ }^{159}$

Since existing federal regulations cannot adequately regulate nanomaterials, and are unlikely to work in the short-term, why not simply create a new set of regulations designed specifically for nanotechnology? The problem comes from the difficulties in the legislative process that would be involved in adopting such regulations. If a whole new set of regulations must be drafted, the nanotechnology industry could go without substantial regulation for too long, as the legislative process may take a long time to develop any substantial regulations. ${ }^{160}$ It is equally unfeasible to assume innovative companies will stop producing until regulations are set. The perceived benefits of nanotechnology are too high. While it is clear that a definite timeframe has been pulled off the table, researchers fear that eliminating the timeframe altogether may allow for the effort to drag on indefinitely. ${ }^{161}$ In fact, it appears that no one is certain when a timeframe will be released or how long the decision to implement a timeframe will take to come into effect.

A lack of timeframe is detrimental to consumer perceptions. Consumers are likely to believe that the trouble with finding an adequate way to regulate nanotechnology reflects nanotechnology's level of danger. In addition, in the short-term, the lack of regulations allows innovative companies to produce without being required to meet stringent safety and health requirements. Clearly, consumers are adversely affected from the lack of regulation.

If the many short-term effects of utilizing existing regulations are not enough, there are also long-term effects of both utilizing these existing federal regulations and failing to decide quickly on adequate regulations. Existing regulations do not regulate nanotechnology per se, but rather, they only regulate products containing nanotechnology. ${ }^{162}$ Thus, it is likely that some form of regulation beyond the existing regulations will eventually be needed. The best option is to make a long-term regulatory decision as quickly as possible.

Substantial oversight in the long-term may be practically impossible because there are so few experts in the individual fields of nanotechnology and researchers are often the only ones qualified to oversee a particular re-

158. See discussion, supra Part III.A.

159. See 29 U.S.C. $\$ \S 651-78$ (2006).

160. Rollins, supra note 26, at 231.

161. EPA Advisers Decide Against Timeline for Nanotech Regulations, InSIDE THE EPA, Dec. 2, 2005, at section 48, available at 2005 WLNR 19334000.

162. As discussed above, the TSCA would regulate nanotechnology as a "new chemical," rather than as a separate category. See discussion, supra Part III.A.1. 
search area. ${ }^{163}$ In contrast, another solution is possible: voluntary programs can act product by product, or industry by industry, to reassure consumers of the precautions taken by nanotechnology companies. This allows federal programs to take the time needed to perfect the regulation decision and then eventually take over the regulatory burden. If consumers are heavily risk averse and there are no adequate regulations, nanotechnology progress could be brought to a standstill. Using a single, existing federal regulation, will be inadequate. Thus, the best decision for the nanotechnology industry is for an entirely new set of nano-specific regulations to be crafted federally. Nevertheless, because of the time commitment required to set these new regulations, something must be done in the interim.

\section{VOLUNTARY REGULATORY PROGRAMS}

\section{A. Proposal for State Level Voluntary Regulatory Program}

A state level voluntary regulatory program could ease concerns over nanotechnology in the short-run. This proposed voluntary program would allow industry to regulate itself, with minimal oversight until adequate federal regulations are chosen. ${ }^{164}$ Then, once one is decided upon, the proper federal regulations can take over. Oversight can be performed not only by the government, but also by private companies and industry groups that coordinate to "articulate standards and create safeguards." 165 When determining regulations, "[i]t is important to achieve an appropriate balance [between varying interests] so that oversight does not stifle innovation or impose unnecessary costs or burdens [on the innovative company]."166 The nanotechnology specific goals for oversight are: "transparency in development, opportunities for public input, accountability to diverse stakeholders, [the] ability to safeguard human and environmental health, and [the] ability to foster innovation."167 Depending on the specific interest group and its individual concerns regarding nanotechnology, each group's rank of these goals may vary drastically. For instance, the public will likely be more in-

163. For example, to oversee the prosecution of patents, the U.S. Patent and Trademark Office ("USPTO") employs 6,292 patent examiners. These examiners review the over 460,000 patents filed each year. Each patent concerns a specialized area of research with which many laymen are unfamiliar. Likewise, nanotechnology regulation would require experts to ensure the regulations are met. Employing a substantial number of experts, as the USPTO does, will be difficult for nanotechnology. See generally Patent Production Model, U.S. PATENT TRADEMARK OFFICE, http://www.uspto.gov/patents/stats/patent pend_model.jsp (last updated May 5, 2010).

164. See, e.g., Int'l Council on Nanotechnology, supra note 129; Nanoscale Materials Stewardship Program, supra note 132. The voluntary program for nanotechnology takes these concepts further by adding incentives to companies for participation.

165. See Paradise et al., supra note 7 , at 408.

166. Id. at 413 .

167. Id. at 415 . 
terested in health and safety, while innovative companies will be concerned with fostering innovation and accountability to stockholders, whilst the government will be concerned with transparency and pubic input.

A state level voluntary program could effectively work as a "band aid" temporarily relieving the problem until a more sufficient, sophisticated solution is discovered. In order for this to occur, each state would need to set standards for participation or negotiate these standards with the innovative companies inside each state. A cohesive state agency or board would be required to oversee the project. The necessary standards may vary with the "state of the industry" in each particular state, but universally required standards would include mandatory reporting of possible hazards and research conducted, as well as health and safety research minimums. Each regulation's level of strictness will depend on to what extent the particular state wants to promote nanotechnology within its borders, and how concerned the state is with being at the forefront of innovation. ${ }^{168}$ Stricter regulations may momentarily stifle innovation, but would also create greater consumer appreciation for those companies that have met the standards. More lenient standards would allow a greater number of products to be released onto the market, yet would also fail to assure consumers of the products' safety.

Once an innovative company complies with the regulations of its state, or meets the standards, the given product should be awarded a special symbol on the label and on the product's website. For occupational safety concerns, a notation could be placed on the company website/employment page, and this special notation would advertise the innovative company's devotion to safety. ${ }^{169}$ The recognition would be good for consumers, potential employees, and federal governmental agencies. As for consumers, the recognition would alert them to the company's standards of excellence and dedication to safety. Hopefully, consumer support would then encourage consumption of products containing nanotechnology, which would in turn transfer back to the innovative company in the form of increased profits.

Potential employees may also be more likely to accept potentially risky employment when they know that the innovative company is concerned with their safety. This would likely attract more qualified employ-

168. See generally Snyder, supra note 30. A voluntary regulatory program would be a good fit for a state like Indiana that houses many Universities and companies currently involved in nanotechnology research. Indiana operations such as Altairnano and Makuta have a dominant position in nanotechnology manufacturing. In Indiana the core driver for research remains at the University level with schools including Purdue University, University of Notre Dame, and Valparaiso University. Accordingly, the regulations set for Indiana would likely be strict, mirroring the state's interest in being a leader of the "nanotechnology revolution."

169. See, e.g., U.S. Envtl. Prot. Agency \& U.S. Dep't of Energy, EnERGY STAR, http://www.energystar.gov (last visited Oct. 27, 2010). The Energy Star logo on household appliances denotes devotion to energy efficiency. 
ees, which would translate to greater productivity, and further increases in profit and innovation for the innovative company. Finally, the voluntary regulatory program can be used as a tool to gather information the federal government as long-term regulations are being crafted. ${ }^{170}$ The program would show what the innovative companies are willing and able to do, what standards appeal to the public at large, and what the emerging health and safety concerns regarding nanotechnology are. Although complying with voluntary regulations may at first be costly to the innovative firm, the projected benefits may likely outweigh the costs. ${ }^{171}$ Indeed, each benefit gained by potential employees, consumers, and the government, should relate back to the innovative company who incurs the cost of compliance.

\section{B. Existing Voluntary Programs in Other Industries}

The existence of successful voluntary programs outside the nanotechnology industry can provide a framework for nanotechnology regulation going forward. These programs demonstrate how a voluntary program could work in the nanotechnology industry. In the past, voluntary programs have been used to reduce environmental concerns. ${ }^{172}$ Voluntary Environmental Programs ("VEPs") "seek to induce firms to produce positive environmental externalities beyond what existing government regulations require." "Environmental Voluntary Agreements [("VAs")] are collaborative arrangements between firms and regulators in which firms voluntarily commit to actions that improve the natural environment."174 In VAs, "the regulator encourages and/or supervises" the actions of the firm. ${ }^{175}$ In the case of VAs, the regulator is the EPA, and in return for firms participating in the program, the EPA publicizes the firms with outstanding pollution prevention achievement. ${ }^{176}$ As VAs have proven to be effective, they can supplement, and sometimes even replace, command-and-control regulation. ${ }^{177}$

Command-and-control regulation is what most people think of when governmental regulation is mentioned. The government sets standards, and

170. The motivation for information gathering in the voluntary program is much like that of the Wisconsin working group that is attempting to gather information on nanotechnology. See Intergovernmental Nanotechnology Working Group, supra note 141.

171. See generally Bray, supra note 145 (highlighting the fact that regulation of recombinant DNA technology in Cambridge, Massachusetts did not stifle innovation).

172. See generally Prakash \& Potoski, supra note 135.

173. Id.

174. Id.; see also Magali A. Delmas \& Ann K. Terlaak, A Framework for Analyzing Environmental Voluntary Agreements, 43 CAL. Mgmt Rev. 44, 44 (2001).

175. Id.

176. See, e.g., State and Local Transportation Resources: Voluntary Programs, U.S. ENVTL PROT. AGENCY, http://www.epa.gov/otaq/stateresources/voluntaryprograms.htm (last updated Oct. 15, 2008).

177. See Delmas \& Terlaak, supra note 174, at 44. 
there is no bargaining or leniency with regard to those standards for any firm. ${ }^{178}$ In fact, the FDCA, TSCA and CPSA are all examples of commandand-control regulation. ${ }^{179}$ Participation is mandatory if a firm wishes to be in the market. ${ }^{180}$

There are two types of VAs: "Negotiated Agreements and Public Voluntary Programs." 181 For Negotiated Agreements, "regulatory agencies and firms negotiate the targets of environmental performance that firms will have to reach," however these targets are not usually legally binding on the firms themselves. ${ }^{182}$ Examples of Negotiated Agreements include the German VA on Global Warming Prevention, ${ }^{183}$ and Project XL. ${ }^{184}$ In both of these programs, firms commit to a higher environmental performance level than what is required under the mandatory standards and regulations. ${ }^{185}$ For example, the Energy Star Program is considered a Negotiated Agreement. ${ }^{186}$ Energy Star Logos are placed on any product that meets or exceeds performance criteria regarding energy efficiency. ${ }^{187}$ The Energy Star logo appeals to customers who care about the environment, as well as those who are interested in saving money through a valuable tax credit program. ${ }^{188}$ Another example of a Negotiated Agreement can be seen in the EPA's Design for the Environment ("DfE"). ${ }^{189}$ DfE partners the EPA with "industry, research institutions, and environmental groups to develop technological solutions to specific environmental challenges." 190 This information is then disseminated among businesses in hopes that the practices will be utilized by others. ${ }^{191}$

178. See, e.g., 21 U.S.C. $\S 360$ (2006).

179. 21 U.S.C. $\S 301-99$ (2006); 15 U.S.C. $\S \S 2601-29$ (2006); 15 U.S.C.A $\S \S 2051-$ 2089 (2006).

180. See generally 21 U.S.C. $\S 301-99 ; 15$ U.S.C. $\S \S 2601-29 ; 15$ U.S.C.A. $\S \S 2051-89$.

181. See Delmas \& Terlaak, supra note 174, at 46.

182. Id. at 46-47.

183. See generally Stephan Ramesohl \& Kora Kristof, The Declaration of German Industry on Global Warming Prevention - a Dynamic Analysis of Current Performance and Future Prospects for Development, 9 J. ClEANER PROD. 437 (2001).

184. See generally Project XL, U.S. EnVTL. Prot. AgEnCY, http://www.epa.gov/ projctxl/ (last updated Sept. 30, 2010).

185. See, e.g., What is Project XL?, U.S. Envtl. Prot. Agency, http://www.epa.gov/projectxl/file2.htm (last updated Sept. 30, 2010); Ramesohl \& Kristof, supra note 183, at 438 .

186. See U.S. Envtl. Prot. Agency \& U.S. Dep't of Energy, supra note 169.

187. See U.S. Envtl. Prot. Agency \& U.S. Dep't of Energy, About Energy Star, ENERGY STAR, http://www.energystar.gov/index.cfm?c=about.ab_index (last visited Oct. 27, 2010).

188. See U.S. Envtl. Prot. Agency \& U.S. Dep't of Energy, Federal Tax Credits for Energy Efficiency, ENERGY STAR, http://www.energystar.gov/index.cfm?c=tax_ credits.tx_index (last visited Oct. 28, 2010).

189. See Design for the Environment, Home, U.S. EnVtl. Prot. Agency, http://www.epa.gov/dfe (last updated Oct. 28, 2010).

190. See Delmas \& Terlaak, supra note 174, at 50; Design for the Environment, supra note 183.

191. See Delmas \& Terlaak, supra note 174, at 50. 
Public Voluntary Programs are set up in a way where regulators establish the framework and basic requirements for participation. ${ }^{192}$ Companies in each industry do not get a say in the regulation standards as they do in Negotiated Agreements. ${ }^{193}$ The EPA's Voluntary Children's Chemical Evaluation Program ("VCCEP") is an example of a VA that includes some of the qualities inherent in this Note's proposed program. ${ }^{194}$ The VCCEP was designed to "give citizens information on the effects of chemicals to enable them to make wise choices in the home and marketplace."195 The focus of the VCEEP is the safety of children with regard to those chemicals. Public Voluntary Programs generally co-exist with current regulations, while those existing regulations remain unchanged. ${ }^{196}$ The Public Voluntary Programs are not intended for radical changes because the voluntary program must still operate within the bounds of the established federal regulations. Accordingly, Public Voluntary Programs ask slightly more of companies, usually in the form of increased reporting to the regulator or an even greater reduction in harm to the environment than federal regulations require. However, in the field of nanotechnology, radical changes must be made to regulate the new science instead of just requiring firms to report more under existing regulations.

The FDA has a program for voluntary labeling of raw fruits, vegetables, and fish. ${ }^{197}$ The company that seeks to produce and sell these items must provide nutrition labeling for at least 90 percent of the raw agricultural commodities listed in the 20 most consumed raw fruits, vegetables, and fish that they sell. ${ }^{198}$ The label must provide certain data as required by the FDA and must be presented in an appropriate manner. ${ }^{199}$ Compliance with code is required for placement of the label on the raw fruit, vegetable, or fish. ${ }^{200}$ Seemingly, this regulation was put in place to assure consumers that each company uses safe handling techniques and processes for raw foods. However, the requirements of 21 C.F.R. section 101.43 are not strict and do not provide substantial benefits for the producer itself, and as a result, the effects are minimal. Thus, a simple labeling standard is unlikely to be adequate for nanotechnology.

192. Id. at 47.

193. Id. at 46-47.

194. See generally Voluntary Children's Chemical Evaluation Program (VCCEP), U.S. Envtl. Prot. AgEnCY, http://www.epa.gov/oppt/vccep/ (last updated Aug. 31, 2010).

195. Id.

196. Delmas \& Terlaak, supra note 174 , at 47.

197. See 21 C.F.R. $\$ 101.43$ (2010).

198. See 21 C.F.R. § 101.43(a) (2010); see also 21 C.F.R. $§ 101.44$ (2010) (listing the 20 most consumed raw fruits, vegetables, and fish).

199. See 21 C.F.R. $\S 101.45$ (2010).

200. The placement on the label is codified, but whether to label at all is voluntary. See 21 C.F.R. $§ 101.43$. 
Wisconsin has proposed a voluntary program for BGH-free milk labeling. ${ }^{201}$ The proposed bill is voluntary, "but a closer read of the labeling legislation reveals that it establishes an extensive regulatory network of mandatory wholesale product labeling and tracking for Wisconsin products only." 202 At the time, Wisconsin Representative Eugene Hahn argued that Wisconsin producers would suffer because of the compliance, and that the voluntary program would eventually force dairy plants out of the state, taking jobs along with them. ${ }^{203}$ Representative Hahn believed the outcome of this bill, would not foster healthy practices in Wisconsin, but force affected companies to relocate to other states that did not "require" the extensive labeling. ${ }^{204}$ This adverse effect for nanotechnology must be carefully avoided. Voluntary regulations must be set at such a level as to encourage innovation and participation in the program at the same time. If requirements are set too high and companies stop producing, the benefits of nanotechnology will be lost.

Though not specific to nanotechnology, a final example of a voluntary regulatory program can be seen in the FDCA's program that requests registration of potentially hazardous cosmetic products. ${ }^{205}$ In addition to being voluntary, the program does not require any sort of toxicity information. ${ }^{206}$ For nanotechnology, the toxicity information is the most important aspect of the proposed voluntary program. However, there are advantages to the FDCA program. The program allows the FDA to gather information on potentially hazardous products that enter the market. ${ }^{207}$ Any sort of information gathering can be used to develop a better future regulatory scheme, and it would be useful for a nanotechnology company to participate in a program like that of the FDCA. Nonetheless, currently, there are no voluntary programs thorough enough to gather adequate information on nanotechnology to design a federal regulation. Incentives would also need to be large enough that nanotechnology companies would spend their own resources to participate.

\section{Advantages of Voluntary Program}

A voluntary regulatory program for nanotechnology has the potential

201. See generally Eugene Hahn, Editorial, BGH Labeling Hurts Wisconsin, CAPITAL TiMEs, Jan. 5, 1994, at 9A.

202. Id.

203. Id.

204. Id.

205. 21 C.F.R. $\S \S 710$, -20 (2010). See generally Voluntary Cosmetic Registration Program (VCRP), U.S. FOOD AND DRUG ADMINISTRATION, http://www.fda.gov/ Cosmetics/GuidanceComplianceRegulatoryInformation/VoluntaryCosmeticsRegistrationProgramV CRP/default.htm (last updated Aug. 6, 2010).

206. Id.

207. Id. 
to realize advantages for innovation, public perception, and health and safety. Additionally, nanotechnology producers will participate in a voluntary program because of the increased profits and reputational benefits.

\section{Innovation}

A voluntary regulatory program will aid innovation because it will reward compliance rather than punishing the failure to comply. The reward for compliance will be designed so that the innovative company recoups the financial cost expended for compliance with increased sales and customer loyalty. In the environmental context, VEPs are believed capable of encouraging proactive industry, reducing transaction costs, and accelerating the achievement of environmental targets, due in part to less legal action and conflict. ${ }^{208}$

\section{Public Perceptions}

Voluntary regulatory programs would positively affect the public perception of the nanotechnology industry. The proposed regulatory program can be used by innovative companies as a strategic tool to "reduce their regulatory burden, develop new . . competencies ahead of competition, and communicate their . . . responsible behavior to customers." ${ }^{209}$ Voluntary programs allow for win-win situations where "[t]he regulator achieves the desired result with decreased enforcement costs, while the regulated community is provided with more flexibility in meeting societal goals - thus eliminating economic inefficiencies." ${ }^{210}$ When social goals are met, the public benefits from not only increased safety but also less apprehension regarding a new technology. Federal regulations, as opposed to state regulations, are the better option to ease consumer apprehension because federal regulations provide a nationally cohesive approach to arising problems. Federal regulations are unlikely to be implemented until far into the future. Consequently, voluntary programs are important for the immediate future. Additionally, VAs can serve to anticipate and shape future federal regulations. Innovative companies will already be familiar with some of the regulations, which allows for a smooth transition to the long-term federal regulations. Those regulatory schemes that appeal to the public can be implemented into long-term regulations.

Awarding labels to participating innovative companies allows for public recognition and confidence in the industry. For example, most consum-

208. See Dinah Koehler, The Effectiveness of Voluntary Environmental Programs - A Policy at a Crossroads?, 35 The PoL'y STUD. J. 689, 691 (2007).

209. See Delmas \& Terlaak, supra note 174, at 44.

210. Dorothy Daley, Voluntary Approaches to Environmental Problems: Exploring the Rise of Nontraditional Public Policy, 35 THE POL'Y STUD. J. 165, 165 (2007). 
ers recognize the Energy Star label as an appliance that is good for the environment and that can lower energy costs. ${ }^{211}$ Thus, with a voluntary regulation and noticeable labels, consumers may feel as though their concerns, in both production and products, are being considered. A lesser fear of the technology, initially and in the future, can be gained by using a voluntary regulatory scheme. ${ }^{212}$ Of course, as consumers buy more nano-containing products, innovation by the participating companies is also likely to increase.

\section{Health and Safety}

Additionally, voluntary programs can be viewed as testing grounds for new practices that may become the industry standard. ${ }^{213}$ This would surely be the case if findings during research such as health and safety risks and preventative practices are distributed to the entire industry. Consumers that value improved environmental or safety performances incentivize innovative companies to continue innovation. Thus, a company can differentiate itself through participation in a voluntary program and a higher price can be set to capture additional market share. ${ }^{214}$ With higher prices and profits come higher levels of innovation as the innovative company has more resources to put into new projects.

Most importantly, a voluntary regulatory program implemented before federal regulations are chosen will have a positive impact on safety. Voluntary programs reward the "good guy" for making the industry safer, rather than punishing the wrongdoer like most regulations. ${ }^{215}$ This is an especially important feature considering we do not yet know what or who the "bad guy" is in nanotechnology. Safety can also be increased through a voluntary regulatory program by attracting more qualified employees to a potentially hazardous industry such as nanotechnology. Participation in the voluntary program may attract potential employees to the innovative company when employees know extra caution is being taken. Finally, as firms agree to higher standards of safety, they are likely to incur less liability in the future. As regulations are met, it is clear that overall safe practices will be used by complying companies.

211. See generally U.S. Envtl. Prot. Agency \& U.S. Dep't of Energy, supra note 169.

212. See, e.g., Voluntary Children's Chemical Evaluation Program (VCCEP), supra note 194.

213. See EPA Launches Effort to Boost Enrollment in Voluntary Programs, CLEAN AIR REPORT, Oct. 18, 2007, available at 2007 WLNR 20378986.

214. See Delmas \& Terlaak, supra note 174, at 52.

215. Wendy Wagner, Using Competition-Based Regulation to Bridge the Toxics Data Gap, 83 IND. L.J. 629, 652-64 (2008). 


\section{Incentives for Firm Participation}

In general, firms will only choose to participate in the voluntary program if they anticipate a net gain following compliance. Therefore, when the benefits outweigh the cost of compliance, a firm will participate. In contrast, when the cost of compliance is not outweighed by the benefits of such compliance, the firm will not participate. If a voluntary program is created to address an industry-wide regulatory threat, but only some firms participate, the resulting information gained will still benefit the entire industry. This may incentivize a firm to free-ride on those participating; meaning companies may enjoy benefits as a direct result of contributions from others. Thus, it is important that firms determine whether "a VA offers a unique opportunity to gain a competitive advantage or the possibility of turning into a costly enterprise. $" 216$

\section{Disadvantages of Voluntary Program}

The disadvantages of voluntary programs must be weighed against the benefits. At least in the short-term, the benefits of a voluntary program outweigh the disadvantages, warranting its use. A voluntary program may be costly to innovative companies. ${ }^{217}$ To reap the benefits of the voluntary program, expenditures have to be made. Assuming a higher level of business will be achieved after compliance, the original outlay of resources is not a detriment. However, when the voluntary program is first initiated, there is no guarantee to the innovative company that satisfactory benefits will follow.

In addition, for a voluntary regulatory program to work, a regulatory agency is still needed to oversee the program and assess the rewards. This may take away manpower from attempting to settle the long debate over concrete federal regulation. However, as proposed, this agency will be at the state level. Those employees also have to be compensated somehow.

Further, if voluntary regulations are promulgated at the state level, as proposed, resources will not be taken away from federal agencies. State regulation incurs other disadvantages, however. Differences in regulation requirements across states could prove to be confusing to consumers. ${ }^{218}$ Even if each state has a different level of compliance that must be met to gain the advantage, consumers are likely to value each level of compliance equally. Thus, companies in a state that has lower levels of compliance will have to expend fewer resources to gain the same degree of benefits. To overcome this problem, more cohesive standards could be set. However,

216. See Delmas \& Terlaak, supra note 174.

217. Id.

218. See Hahn, supra note 201. 
the remedy simply brings back the problems that federal regulation would create. Thus, some amount of inefficiency is going to result when attempting to address the hazards of nanotechnology.

For some level of cohesiveness between the state programs, a common label or symbol that is awarded to complying companies could be developed. As developing a symbol should not take a long period, one state may be able to take the reins, develop the symbol, and give it to other states to use. It is important that the symbol is the same across state lines so that consumers are easily familiarized with nano-containing products and so that those products can travel in both inter and intra state commerce. That way the innovative company will benefit even when its products are transported across state lines.

Negotiation and administrative costs that arise from forming the voluntary agreement may be too high for some companies. However, these costs can be reduced by the state agency setting the requirements, instead of costly negotiations occurring. However, this leads back to the original problem that those with the most knowledge of the industry, work in the industry and not for government. ${ }^{219}$ It may also pose a problem regarding the ability of the regulator to maintain a consistent way of defining evaluating, and creating new voluntary programs. ${ }^{220}$ Generally, the state of the industry as it is (unregulated) benefits the manufacturing community because of the reduced amount of research expenditure that is necessary. Thus, pressure from industry professionals for greater regulatory oversight does not exist, or is weak at best. ${ }^{221}$

Further disadvantages mirror those of self-regulation. Disclosure to government always carries the risk that competitors will discover proprietary information about a company through information sharing. ${ }^{22}$ This is due to the government's incentive to create social benefits by sharing information with all. ${ }^{223}$ Additionally, the "production and distribution of information is costly." 224 Free-rider problems may arise if a firm feels it can shirk responsibilities and still gain benefits from increased knowledge or public perception based on the participation of other firms. ${ }^{225}$

In Chamber of Commerce v. U.S. Department of Labor, a governmental agency's implementation of a voluntary regulatory program that had yet to undergo a formal rulemaking process had violated statutory and constitu-

219. See EPA Launches Effort, supra note 213.

220. Id.

221. Wagner, supra note 215 , at 656.

222. See generally Mary Lyndon, Secrecy and Access in an Innovation Intensive Economy: Reordering Information Privileges in Environmental, Health and Safety Law, 78 UNIV. COL. L. REV. 465 (2007).

223. See generally Alan Devlin, The Misunderstood Function of Disclosure in Patent Law, 23 HARV. J.L. \& TECH. 401, 402 (2010).

224. See Rollins, supra note 26, at 232.

225. See Zycher et al., supra note 59. 
tional protections, and ultimately, the challenged program claimed to be voluntary but had provisions that imposed mandatory sanctions. ${ }^{226}$ A truly voluntary program is acceptable if it comes in to effect absent a formalized process; however, once penalties are written in, constitutional protections may be crossed. ${ }^{227}$

Implementing a voluntary program for nanotechnology will undoubtedly provide both advantages and disadvantages. However, in the case of nanotechnology, where the future of the regulations and the industry is generally uncertain, the advantages of increased knowledge and production will likely to outweigh the disadvantages. Further, the disadvantages for the proposed program will not accumulate since the program is not a permanent solution, but a temporary fix.

\section{E. How a State Level Program Would Look}

The state level voluntary regulatory program for nanotechnology would require innovative companies to report the products being researched and products that contain nanomaterials, to a designated state agency. In addition, the type of nanomaterial used, and the known risks of that nanomaterial will need to be disclosed. For the company to receive the benefits of the program, it will also have to meet a certain research minimum, along with reporting what is being done internally to reduce the potential risks of nanomaterials. These reports will be required annually along with a showing that competent research is being done to assess potential risks.

Minimum requirements would ideally be set by the federal government, and any further requirements may be determined on a state-by-state basis. However, the entire program may be state run in order to streamline the process if necessary. Additionally, the specific research levels and safe practices are determined based on the type of industry that is producing or researching nanotechnology. For example, a university would likely have to meet a greater research minimum than a small independent company in order to be deemed compliant with the regulations. Universities will also have to focus efforts on safe handling practices rather than consumer safety, as they are not producing products for the market. Large producers will also have to meet a larger research minimum, and be expected to share those results among one another, because the larger companies are likely to have the manpower and resources available to meet stricter regulations as compared to small and start-up companies. As a result, larger companies will be able to provide the greatest benefit to consumers and the government.

226. See Chamber of Commerce of the U.S. v. U.S. Dep't of Labor, 174 F.3d 206 (D.C. Cir. 1999).

227. Id. 
Research results (only regarding health and safety, not specific innovations) would be anonymous when released to the state agency. Innovative companies would then be able to build off one another's experience to better equip the nanotechnology industry to deal with health and safety issues. Sharing information also ensures that multiple research projects that come to the same safety conclusion do not have to overlap. Available resources can then be used more productively.

Once the given level of compliance is met, the company, university, etc. would be rewarded. The reward would be two-fold. First, it would allow the complier to label the products it produces with a label that denotes its dedication to the research and safety of nanotechnology. ${ }^{228}$ The notation would also be available on the product, or company, website. The hope is that this notation will put consumers on notice that the products they use contain nanomaterials and that the company producing such nanomaterials is concerned with overall health and safety issues. If the innovative company admits to the presence of nanotechnology, and shows that substantial research is being done, consumer apprehensions are likely to be eased with the disclosure. Thus, the company can continue producing and innovating without fear of unnecessary liability, or loss of sales. Second, the notation could also be placed on the company's website or hiring page. ${ }^{229}$ This notation would alert potential employees of that company's efforts to protect employees from the potentially hazardous effects of nanotechnology.

To get the voluntary program up and running, each state in conjunction with local industry would be advised of a six-step framework. ${ }^{230}$ This would help to determine the levels of compliance necessary in the given state and across industries in order for the program to attain the intended benefits. The framework proposed by Environmental Defense and the DuPont Corporation is a good starting point and includes: 1) developing a description of the nanomaterial based on existing information; 2) developing profiles based on "inherent hazards and associated exposures," and discussing how such profiles are likely to change in the lifetime of the nanomaterial; 3) evaluating available information so as to "identify and characterize the nature, magnitude, and probability of risks"; 4) evaluating risk management options and recommending an appropriate course of action; 5) engaging key stakeholders to determine whether to continue development, or whether to continue already utilized risk management techniques; and 6) regularly updating and re-executing risk evaluations."231

228. See, e.g., Project XL, supra note 178; U.S. Envtl. Prot. Agency \& U.S. Dep't of Energy, supra note 169.

229. See Kristen Kulinowski \& Matthew Jaffe, supra note 131, at 38-41 (detailing the creation of "The GoodNanoGuide" which seeks to encourage good occupational health and safety practices).

230. Linkov et al., supra note 92, at 208.

231. Id. 
This process should be repeated and compliance standards updated every few years until mandatory federal regulations are finalized. Ideally, this process would not only increase safety in conducting nanotechnology research, but also push for a new, permanent federal regulatory scheme for nanotechnology.

\section{CONCLUSION}

A voluntary regulatory scheme for the nanotechnology industry is the best option among the many proposed but imperfect solutions to bring about immediate results. A voluntary scheme will incentivize research into the potential hazards of nanomaterials, increase public perception of the industry, and stimulate innovation. While voluntary regulations are unlikely to provide sufficient long-term protection for the nanotechnology industry the benefits of implementing a state run voluntary program in the short run are great. As long-term federal regulation has not been chosen, and the process of implementing federal regulations takes time, voluntary regulations can fill the gap. Without sufficient oversight of nanotechnology, the safety of factory workers and consumers buying products could be at risk. It is not a certainty that nanotechnology will have the same long-term effects as asbestos; however, the risk should not be allowed to materialize. The current uncertainty with the lack of oversight could preclude consumers from ever having confidence in nanoparticle products. Consumer apprehensions will ultimately stifle innovation of what is a breakthrough technology. When health and safety are at issue, action must be taken as soon as possible. Ultimately, in the case of nanotechnology, a voluntary program that noticeably awards superior participation can ease the current state of nanotechnology, and at the same time, leave federal regulations to contemplate the future. 
